\title{
Characterization of Mullite Ceramic Membranes and their Application in the Removal Escherichia Coli
}

\author{
Dionisio da Silva Biron ${ }^{a}$,Jordana Bortoluz $z^{a}$, Mara Zeni ${ }^{a}$, C. P. Bergmann ${ }^{b}$, Venina dos Santos ${ }^{a *}$ \\ ${ }^{a}$ Center of Exact Sciences and Technology, University of Caxias do Sul (UCS), Caxias do Sul, RS, Brazil \\ ${ }^{b}$ School of Engineering, Federal University of Rio Grande do Sul (UFRGS), RS, Porto Alegre, Brazil
}

Received: May 25, 2015; Revised: February 29, 2016; Accepted: March 1, 2016

\begin{abstract}
This paper aims the morphological and structural characterization of ceramic membranes of mullite and their application in the removal of Escherichia coli. A complex irregular structure presented by the pores of the membrane was verified by scanning electron microscopy (SEM). The average pore size and distribution were determined by mercury intrusion porosimetry. The average pore size of the material presented was $0,39 \mu \mathrm{m}$. Microfiltration tests resulted in a protein retention of 46,76 and $89 \%$ for trypsin (TR), egg albumin (EA) and bovine serum albumin (BSA), proving the efficiency of the membrane microfiltration tests for molecular weight of $69 \mathrm{kDa}$. The application of the membranes on the retention of gram-negative bacterium $E$. coli resulted in a $66 \%$ efficiency at a pressure of $200 \mathrm{kPa}$ and a $98 \%$ efficiency when applied a pressure of $50 \mathrm{kPa}$. Therefore, the use of mullite membranes show limited efficiency towards bacteria retention. Nevertheless, they present fluxes similar to other materials proposed in the literature.
\end{abstract}

Keywords: Characterization, Ceramic membranes, Microfiltration, Retention.

\section{Introduction}

The search for technologies that provide better quality and greater ease in treatment processes becomes one of the main subjects studied today. The process of separation by membrane (PSM) is a technology that has gained prominence because of its advantages compared to conventional separation procedures ${ }^{1,2}$. However, a major problem presented by the membranes is the decrease in permeability over its use due to fouling caused by organic matter contained in the raw water and microorganisms that adhere to the microporous wall or inside the pores ${ }^{3,4}$.

Many studies described in literature proved that the use of ceramic membranes offer several advantages over the polymer ones, especially with respect to durability, resistance to high temperatures and pressures, easy clean condition, biological stability and chemical inertness ${ }^{5,6}$. The main drawback presented by ceramic membranes is their high cost, due to the used raw materials that are imported and synthetic ${ }^{7,8}$. Compared to traditional methods such as distillation and centrifugation, the use of ceramic membranes in water treatment processes have low power consumption and occupy less physical space ${ }^{9,10}$. Many ceramic materials have been used in the manufacture of membranes, among which stand out alumina, silicon oxide, zirconia, titania, mullite and cordierite ${ }^{11-13}$.

The mineral mullite is the only crystalline phase stable intermediate in the binary system $\mathrm{Al}_{2} \mathrm{O}_{3}-\mathrm{SiO}_{2}$ in the range 70.5 to $74.0 \%$ by weight $\mathrm{Al}_{2} \mathrm{O}_{3-} \mathrm{SiO}_{2}$ at atmospheric pressure. In recent years, mullite has had increasing applications in the field of advanced, structural and functional ceramic, in response to its excellent physical properties such as low thermal

*e-mail: vsantos2@ucs.br expansion $\left(4.5\right.$ to $\left.5.6 \times 10^{-6}{ }^{\circ} \mathrm{C}^{-1}\right)$, low thermal conductivity $\left(0.06 \mathrm{~W} \cdot \mathrm{cm}^{-1} \cdot \mathrm{K}^{-1}\right)$, high melting point $\left(>1800^{\circ} \mathrm{C}\right)$ and low

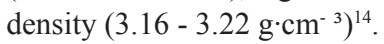

In this study tubular and microporous ceramic membranes of mullite were characterized and implemented in separation processes in order to retain the bacteria Escherichia coli. The control of microorganisms is a major concern in the production of drinking water for human consumption and in the medical field. The World Health Organization (WHO) recommends that all water intended for human consumption should contain zero CFU (Colony Forming Units) of Escherichia coli per $100 \mathrm{~mL}$ of sample. Numerous chemical and physical processes are proposed such as the use of free chlorine and ozone, ultraviolet radiation and filtration. However, some of these processes can bring about undesired effects to humans. Given this context, there is an alternative PSM, which uses the microporous membrane retaining microorganisms ${ }^{15-17}$.

\section{Experimental}

\subsection{Materials}

The mullite tubular ceramic membranes (Figure 1) were provided by Tecnicer-Cetebra, São Carlos, São Paulo, Brazil. The sintering temperature was $1150^{\circ} \mathrm{C}$. The effective membrane area of $52 \mathrm{~cm}^{2}$ corresponds to a length of $210 \mathrm{~mm}$, inner diameter of $8 \mathrm{~mm}$ and $2 \mathrm{~mm}$ of thickness with an average pore size of $0,39 \mu \mathrm{m}$.

The proteins used for microfiltration tests were trypsin, egg albumin and bovine serum albumin, which have molecular weights of 20,45 and $69 \mathrm{kDa}$, respectively. The purpose 
of this was to obtain the molecular weight cut-off of the ceramic membranes evaluated. Table 1 shows the physical characteristics of the studied proteins.

\subsection{Characterization of the membranes}

\subsubsection{Morphology and composition of the membranes}

The analysis by scanning electron microscopy (SEM) and energy dispersive spectroscopy (EDS) of the surface and cross section of the composite membrane were performed using scanning electron microscope (Scanning Electron Microscopy) ZEISS SEM-LEICA/400 coupled to an detector EDS. The membranes were fractured and metallized by sputtering with a thin gold layer prior to their characterization.

\subsubsection{Porosimetry by mercury intrusion}

The pore size and distribution were determined by mercury intrusion porosimetry. The analysis was performed on a porosimeter brand Quantacrhome, model PM-60-17 at the Institute of Ceramic Materials (ICM) of the University of Caxias do Sul (UCS).

\subsubsection{Permeate flux with pure water}

All microfiltration tests were performed in a bench system (Figure 1). The system comprises a 3-liter feed tank, a pumping system with a diaphragm pump with three chambers with positive displacement and an engine of Permanent Magnet P/N 11-155-05. The flux rate used was $0.93 \mathrm{~L} \cdot \mathrm{min}^{-1}$ corresponding to a Reynolds number of 2630 .

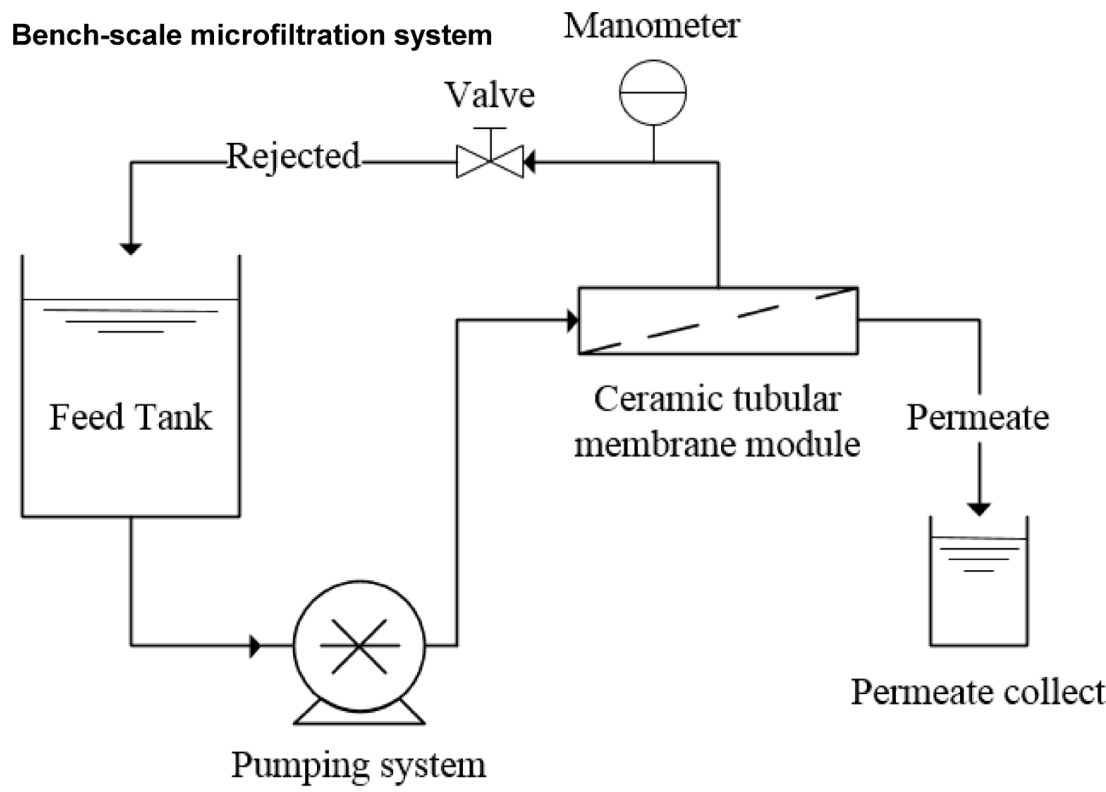

\section{Membrane}

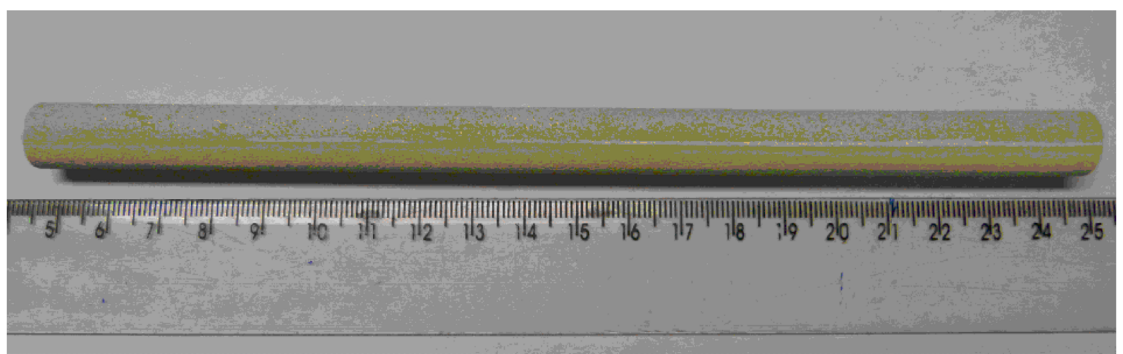

Figure 1. Microfiltration system and mullite ceramic membrane.

Table 1 - Permeate flux presented by membranes for the different proteins used in this study. The fluxes were measured at transmembrane pressure of $100 \mathrm{kPa}$.

\begin{tabular}{cccc}
\hline Proteins & $\begin{array}{c}\text { Molecular weight } \\
(\mathbf{k D a})\end{array}$ & $\begin{array}{c}\text { Average solute radius }(\mathbf{n m}) \\
\text { Average flux } \\
\left(\mathbf{L} \cdot \mathbf{m}^{-2} \cdot \mathbf{h}^{-1}\right)\end{array}$ \\
\hline TR & 20 & 2.15 & $80.2 \pm 5.2$ \\
EA & 45 & 3.30 & $34.9 \pm 2.1$ \\
BSA & 69 & 4.50 & $28.6 \pm 4.3$ \\
\hline
\end{tabular}


The tubular ceramic membrane was characterized by distilled water permeation flux behavior at a pressure of $100 \mathrm{kPa}$, calculated according to Equation 1. The experiment time was $60 \mathrm{~min}$. Protein retention study was performed using protein solutions of different molecular weights, trypsin (TR) (20 kDa), egg albumin (EA) (45 kDa) and bovine serum albumin (BSA) $(69 \mathrm{kDa})$. The protein solutions were individually prepared at a concentration of $100 \mathrm{ppm}$.

Firstly, tests were performed with distilled water and then with proteins in the following order: TR, EA and BSA. For each test performed was used a new membrane. Experiments were performed in triplicate to the tests with distilled water and protein solutions. At the end of experiments with proteins was performed chemical cleaning of the membranes (sodium hypochlorite $3 \%(\mathrm{v} / \mathrm{v})$ ) and posteriorly were performed tests with distilled water in order to check the recovery of the water flux.

During the tests, the flux rates from single protein solutions were measured at a constant pressure of $100 \mathrm{kPa}$. Samples of feed and permeate were collected every $20 \mathrm{~min}$ for measurements of membrane retention efficiency. Protein concentrations were measured from the absorbance readings at a wavelength of $280 \mathrm{~nm}$ using a UV spectrophotometer Genesys 10UV, Termo Spectronic (UV-Visible). The absorbance was converted to concentration by the use of a standard absorbance curve versus protein concentration. The retention of protein $(\% \mathrm{R})$ was calculated by Equation 2.

$$
\begin{aligned}
& J_{w}=\frac{V}{A \cdot \Delta t} \\
& \% R=\left(1-\frac{C_{p}}{C_{f}}\right) x 100
\end{aligned}
$$

where $\mathrm{J}_{\mathrm{w}}$ is the water flux $\left(\mathrm{L} \cdot \mathrm{m}^{-2} \mathrm{~h}^{-1}\right), \mathrm{V}$ is the permeated volume ( $\mathrm{L}), \mathrm{A}$ is the permeating area of the membrane $\left(\mathrm{m}^{2}\right), \Delta \mathrm{t}$ is the permeation time considered ( $\left.\mathrm{h}\right), \% \mathrm{R}$ is the retention percentage, $\mathrm{C}_{\mathrm{p}}$ is the protein concentration in the permeate solution and $\mathrm{C}_{\mathrm{f}}$ is the protein concentration in the feed solution.

\subsection{Microbiological experiments}

\subsubsection{Microbiological culture medium}

Before starting the crossflow microfiltration experiments to evaluate the retention of ceramic membranes a survey of the growth curve of the bacteria $E$. coli was performed to standardize the bacterial contamination in solution. The growth curve was performed by counting bacteria in Petri dishes and in parallel, for spectrophotometric analysis of the optical density (turbidity analysis) with a reading wavelength of $600 \mathrm{~nm}$. The used Escherichia coli suspensions in water have a concentration of $\sim 10^{5} \mathrm{CFU} \cdot \mathrm{mL}^{-1}$.

Nutrient Broth (Merck) was used in the preparation of a liquid culture medium for growth of E. coli bacteria at concentration of $8 \mathrm{~g} \cdot \mathrm{L}^{-1}$. Cells of $E$. coli bacteria were inoculated in $50 \mathrm{~mL}$ of solution containing nutrient broth and incubated at $35^{\circ} \mathrm{C}$ for $24 \mathrm{~h}$. After, $10 \mathrm{~mL}$ this solution spiked with $E$. coli bacteria was added in $1 \mathrm{~L}$ of sterile distilled water, providing a quantity of $\sim 10^{5} \mathrm{CFU} \cdot \mathrm{mL}$. Were necessary dilutions up to $10^{-5}$ para realizar a contagem das CFU.

\subsubsection{Application of ceramic membranes in retaining Escherichia coli}

The permeability and selectivity of the solution containing the gram-negative bacterium Escherichia coli were calculated according to Equations 1 and 2, respectively. The tests were performed under pressures of 50,100, 150 and $200 \mathrm{kPa}$. The experiment time was $60 \mathrm{~min}$. Each test was performed in triplicate. For each test in triplicate was used a new membrane. Samples of feed and permeate were collected every $20 \mathrm{~min}$ for measurements of membrane retention efficiency. Was performed plating of feed and permeate streams. Then the plates were incubated at $35^{\circ} \mathrm{C}$ for $24 \mathrm{~h}$.

\section{Results and discussion}

\subsection{Characterization of tubular ceramic membranes - pore diameter and morphology}

The morphology of tubular ceramic membranes, evaluated by SEM, can be seen in Figure 2. It is observed that the membrane structure is characterized by irregularly distributed pores with a relatively complex shape. This feature is a peculiarity promoted by the process of getting this

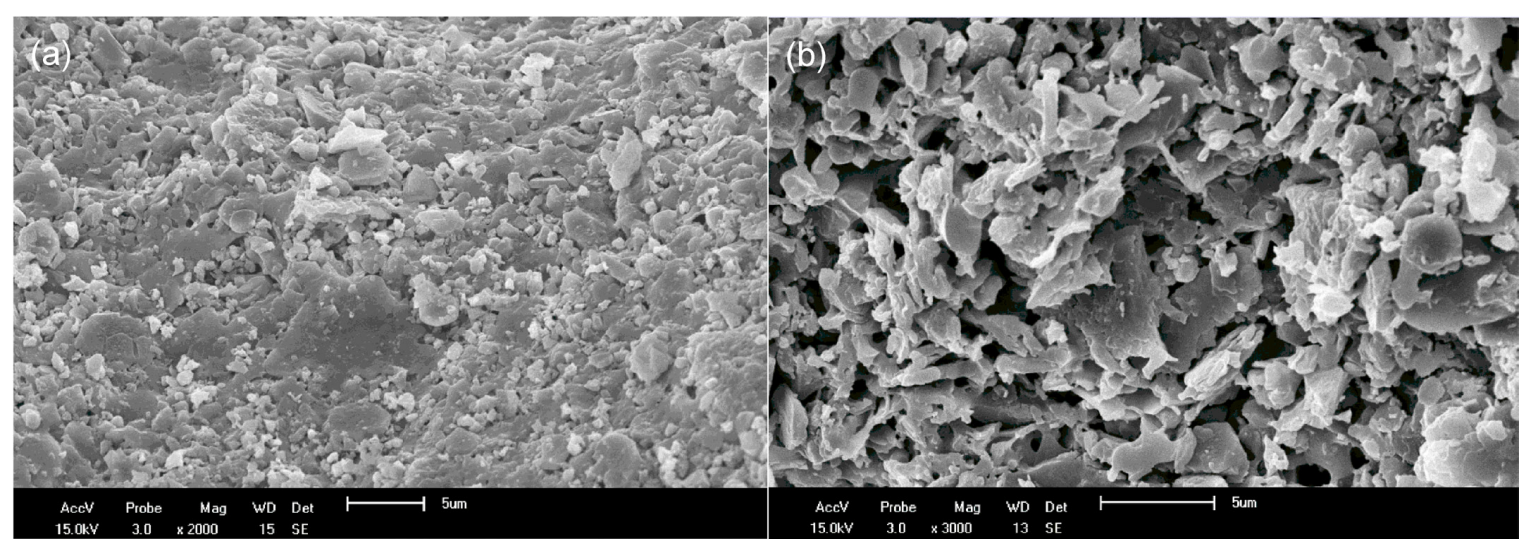

Figure 2. Scanning electron microscopy (SEM) of the tubular ceramic membrane (a) surface and (b) cross section. 
material and its own characteristic structural arrangement. This confirms the highly porous structure with a homogeneous pore distribution. The pores are randomly shaped. At the same time, we notice the absence of macro-defects such as cracks. These features are important for the fabrication of quality supports. The surface quality of the support is important for the efficiency of microfiltration ${ }^{18-20}$.

Figure 3 shows the result of the composition by energy dispersive spectroscopy of the tubular ceramic membrane. It can be seen peaks relating to aluminium, oxygen and silicon demonstrating that the ceramic membrane tube consists of alumina and silicon oxide. According to the manufacturer, this material has $65 \%$ alumina $\left(\mathrm{Al}_{2} \mathrm{O}_{3}\right)$ and $35 \%$ silica $\left(\mathrm{SiO}_{2}\right)$. The presence gold occurred due to coating of a thin layer of the same sample for analysis by SEM.

The pore size distribution for the mullite ceramic membrane can be seen in Figure 4a. This shows the plot of the derivative of the cumulative curves, $\mathrm{dV} / \mathrm{d}$, versus the pore diameter of the studied ceramic membrane. The $\mathrm{dV} / \mathrm{d}$ function is widely used for determination of diameter which occurs in the penetration of the maximal mercury.

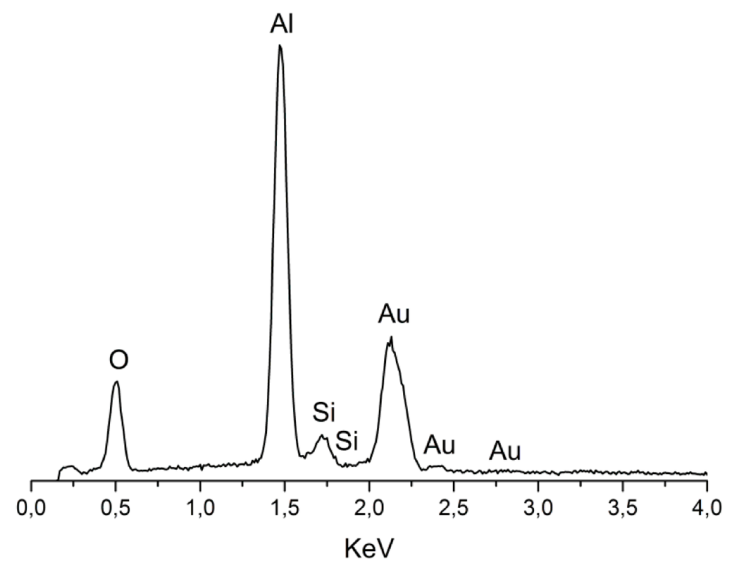

Figure 3. Energy dispersive spectroscopy (EDS) of the tubular ceramic membrane.
Analyzing the profile presented by ceramic membranes illustrated in Figure 4a, there is a predominant presence of pores with diameters of 0.13 to $2.21 \mu \mathrm{m}$, indicated by the appearance of a broad peak in this pore diameter range. The quantification of the distribution of pore size can be obtained from the volume distribution as a function of the diameter, Dv (d), which presents the change in the volume of mercury intruded per interval unit of the pore diameter.

Figure $4 \mathrm{~b}$ shows the mercury intrusion curve as a function of pore size for mullite ceramic membrane. Initially there was a intense increase in the mercury intrusion volume, and subsequently a constant region of intrusion. According Lowell and Shields, this behavior is characteristic of powder samples and depends on the size, shape and geometry of the particle packing ${ }^{21}$. The initial intrusion observed in the samples studied occurred at very low pressures, due to the penetration of mercury in interparticle spaces of the sample. This behavior is characteristic of powder samples and depends on the size, shape and geometry of the particle packing ${ }^{22}$. Thus, the interparticle voids of various dimensions will be filled progressively with increasing pressure. The average volume of mercury intruded in mullite ceramic membranes was $0.08 \mathrm{~cm}^{3} \cdot \mathrm{g}^{1}$.

The cumulative specific surface area of the studied ceramic membranes, calculated from the porosimetry data, was $0.215 \mathrm{~m}^{2} \cdot \mathrm{g}^{-1}$. This value is considered to be relatively low when compared to the specific surface area of some inorganic materials such as catalysts ${ }^{22,23}$. However, this value has the same order of magnitude as those found for other ceramic membranes of the same pore size measured by mercury porosimetry ${ }^{22}$. The low surface area values found for the ceramic membranes can be attributed to the predominance of macropores $(\phi>50 \mathrm{~nm})$, since small pores are responsible for high specific surface area values ${ }^{21}$. The contribution of large pores (macropores) is not very significant in determining the specific surface area.

Figure 5 shows the permeate flux results for the mullite tubular ceramic membrane. The tests were conducted with distilled water and protein solutions.

Ceramic membranes averaging initial permeate flux of $1.9 \times 10^{2} \mathrm{~L} \cdot \mathrm{m}^{-2} \cdot \mathrm{h}^{-1}$ to microfiltration distilled water in a time of $60 \mathrm{~min}$. It can be seen that the molecular weight
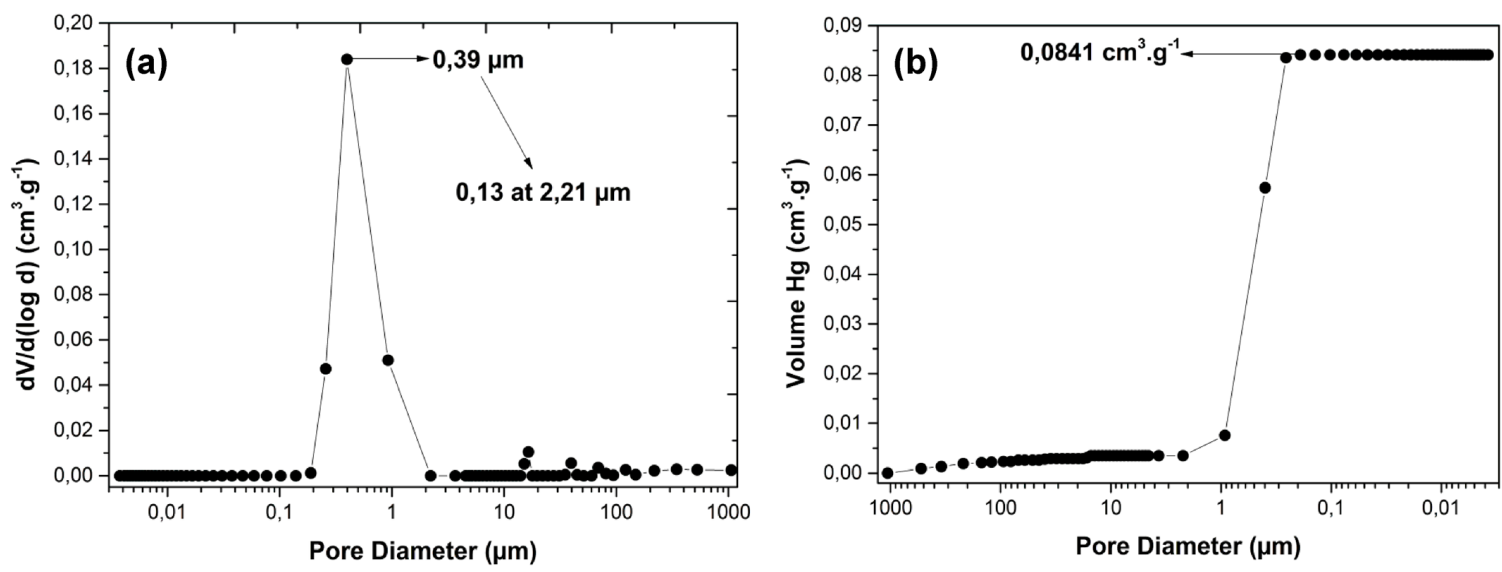

Figure 4. Pore size distribution by mercury intrusion porosimetry of tubular ceramic membrane of mullite. 
of proteins directly influence the permeate flux. As can be seen in Table 1, the molecular weight and the average radius size of the proteins influence on permeated flux of the membrane. The decrease in permeate flux occurred with increasing molecular weight and the molecular radius of the proteins studied. The decrease in average flux observed with the filtration of a protein solution with a higher weight can be interpreted based on total blockage of some pores or due to an increase of a molecular layer of adsorbed protein on the inner surface of pores of membranes.

Figure 6 shows the result of protein retention for the ceramic membrane. A decline of the permeate flux occurred with the increase in molecular weight and thus an increase in the efficiency of membrane separation of solute (protein) of distilled water. The ceramic membrane showed retention of 46,76 and $89 \%$ for TR, EA and BSA, respectively. This result leads us to make a reference to the adequate treatment of wastewaters with contaminant of molecular weight above $69 \mathrm{kDa}$ by microfiltration with this ceramic membrane. As shown in Figure 6, it shows high retention capacity.

\subsection{Application of ceramic membranes in the retention of the E. coli bacteria}

Figure 7 shows the permeate flux results for the mullite ceramic membrane with distilled water containing $E$. coli and sterile distilled water. Firstly, were performed tests

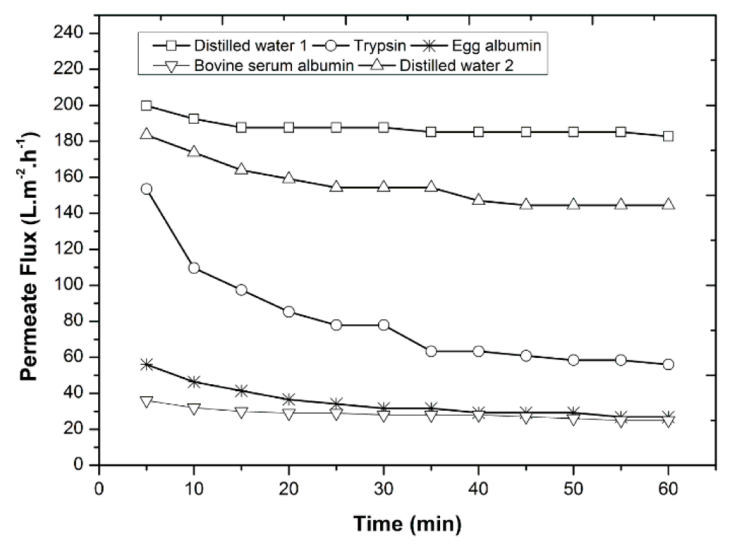

Figure 5. Permeate flux to distilled water and different proteins.

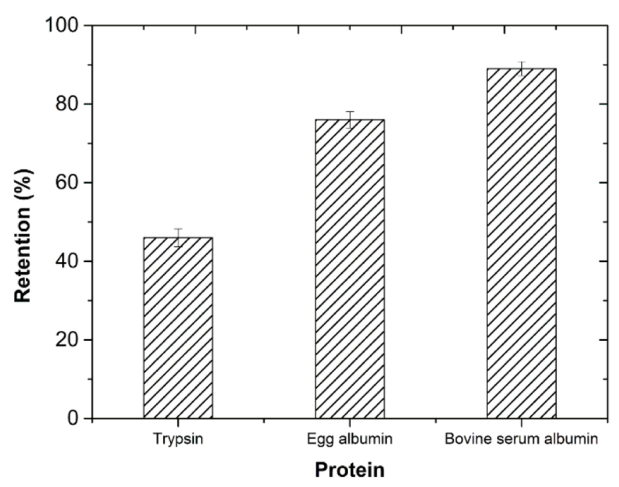

Figure 6. Retention of ceramic tubular membranes for different proteins. with sterile distilled water, followed of tests with distilled water containing $E$. coli bacteria and after sterilization and chemical cleaning of the membrane were performed tests with sterile distilled water again. The increased pressure directly influenced the increase of permeate flux, however one can observe the presence of the microorganism reduces the permeate flux ${ }^{14}$. After chemical cleaning with sodium hypochlorite solution $(3 \% \mathrm{v} / \mathrm{v}) 89 \%$ of the initial flux was recovered in the permeate stream.

Figure 8 shows the retention results of the filtration of E. coli suspensions at different transmembrane pressures, from experiments reported in Figure 7. With increasing pressure there was a decrease in retention, yet the $E$. coli retention efficiency of the membrane at different pressures was low (66\% under $200 \mathrm{kPa}$ and $98 \%$ under $50 \mathrm{kPa})$, demonstrating the membrane mullite proposal can be an interesting alternative to be used in bacteria-retaining processes, however the presence of bacteria demonstrates a need for improvement in the proposed material.

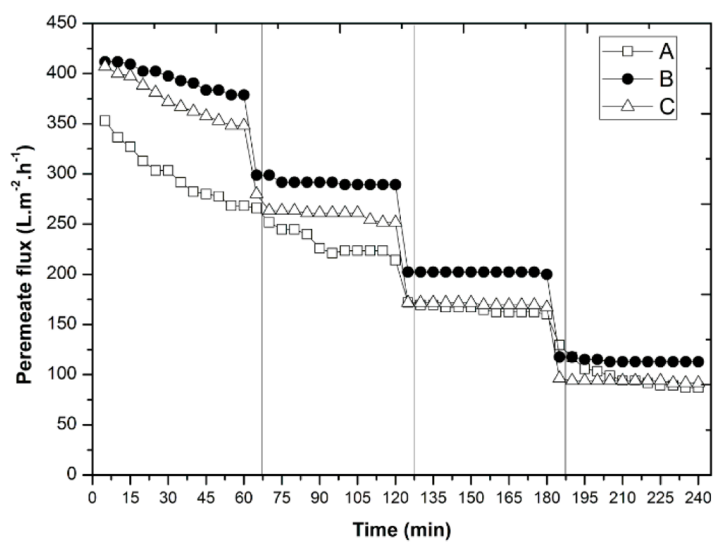

Figure 7. Permeate flux to the mullite tubular membrane tested at different pressures. Where $\mathrm{A}$ is distilled water containing Escherichia coli, B the initial test with distilled water and C the test with distilled water after the test A after membrane cleaning with sodium hypochlorite $3 \%(\mathrm{v} / \mathrm{v})$.

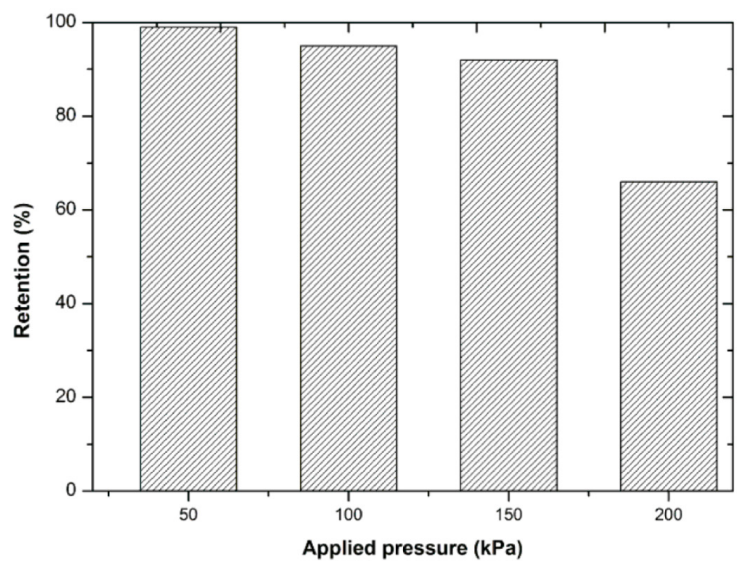

Figure 8. Retention of Escherichia coli bacteria at different pressures applied to the mullite tubular ceramic membrane (alumina and silica). 

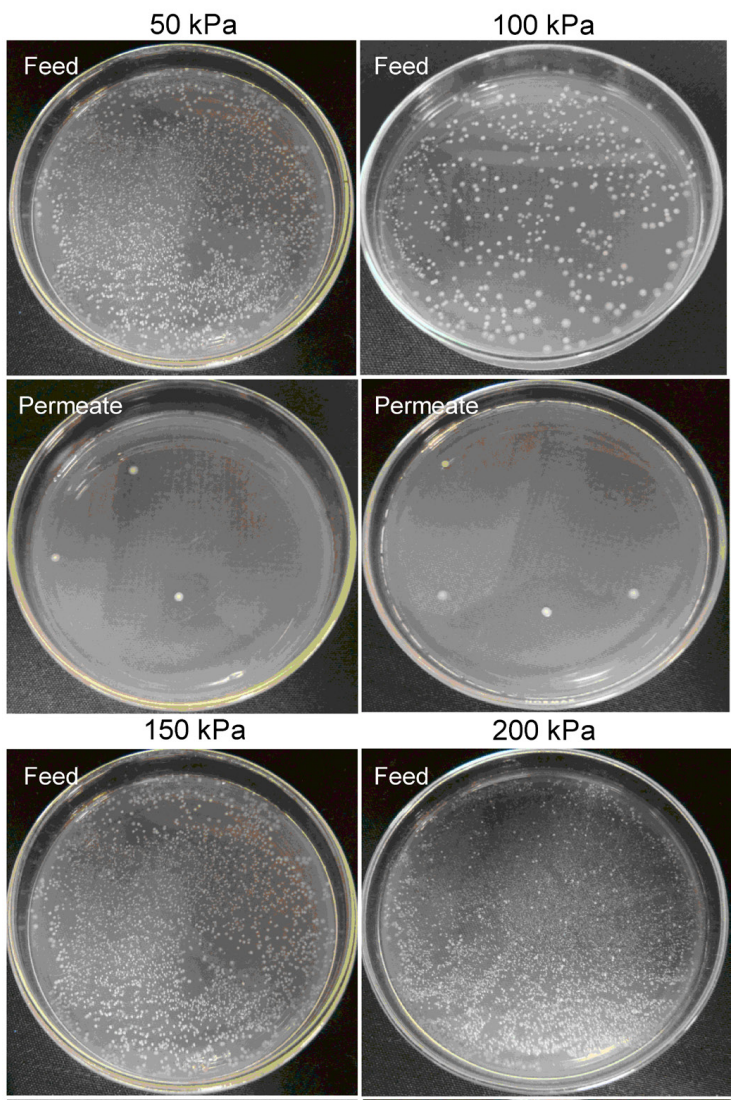

$200 \mathrm{kPa}$
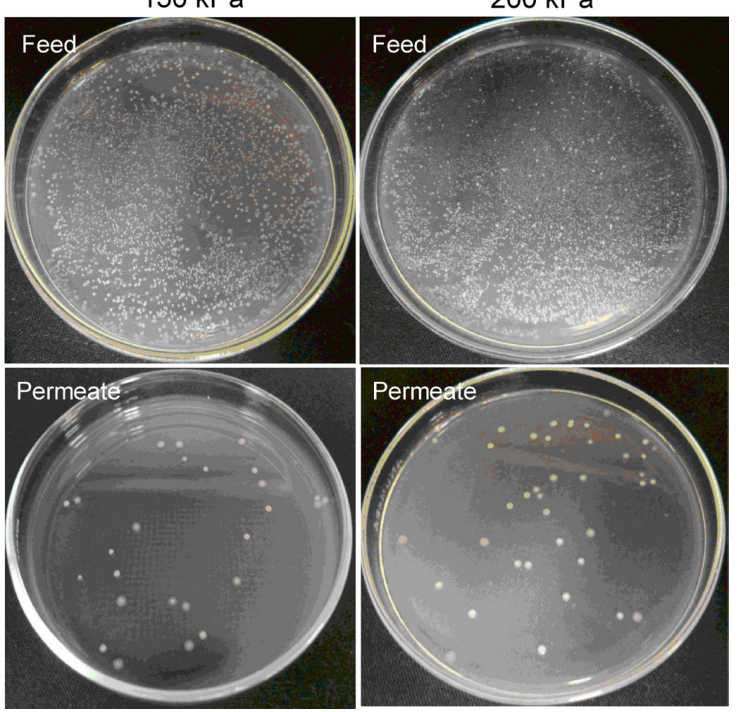

Figure 9. Images of Petri plates inoculated with feeds and permeates from experiments reported in Figure 7 after incubation.

\section{References}

1. Li NN, Fane AG, Ho WS, Matsuura T. Advanced membrane technology and applications. New Jersey: Wiley \& Sons; 2008.

2. Benito JM, Conesa A, Rubio F, Rodríguez MA. Preparation and characterization of tubular ceramic membranes for treatment of oil emulsions. Journal of the European Ceramic Society. 2005:25(11):1895-1903. http://dx.doi.org/10.1016/j. jeurceramsoc.2004.06.016.

3. Zhao F, Xu K, Ren H, Ding L, Geng J, Zhang Y. Combined effects of organic matter and calcium on biofouling of nanofiltration membranes. Journal of Membrane Science. 2015: 486(15):177188. http://dx.doi.org/10.1016/j.memsci.2015.03.032.

4. Jeong S, Vigneswaran S. Practical use of standard pore blocking index as an indicator of biofouling potential in seawater desalination. Desalination. 2015:365:8-14. doi:10.1016/j. desal.2015.02.015
Figure 9 shows the images of $E$. coli colonies incubated in Petri plates that had been inoculated with the permeated and feed streams from filtration experiments reported in Figure 7. The significant retention of bacteria could be seen. However, the results obtained show that the rejection of E. coli by membrane is insufficient, since water for human consumption must be free of microorganisms. By obtaining a $\log$ reduction of less than 2 the membrane proves to be ineffective for bacteria control. These results were expected by the previous pore size distribution characterization that showed the existence of a large fraction of membrane pores above $0.45 \mu \mathrm{m}$.

\section{Conclusions}

The characterization of ceramic membranes showed a free material cracks, however with pores distributed unevenly. The flux rate with distilled water resulted in an average of $1.9 \times 10^{2} \mathrm{~L} \cdot \mathrm{m}^{-2} \cdot \mathrm{h}^{-1}$ and retention of the protein was 46,76 and $89 \%$ for trypsin, egg albumin and bovine serum albumin, respectively. The SEM showed an irregular structure and pore malformed. Despite this characteristic, it was demonstrated that the ceramic membrane is highly selective and can be used in microfiltration process using solutes with molecular weight above $69 \mathrm{kDa}$.

The permeation tests of $E$. coli solution with the ceramic membrane showed fluxes around $400 \mathrm{~L} \cdot \mathrm{m}^{-2} \cdot \mathrm{h}^{-1}$ at $200 \mathrm{kPa}$ transmembrane pressure (TMP). At this TMP a decrease over time occurred while for lower TMPs $(150,100$ and $50 \mathrm{kPa})$ no or a minor flux decrease was observed. By cleaning the membrane with sodium hypochlorite it was possible to recover $89 \%$ of the permeate flux. The retention of Escherichia coli ranged from $66 \%$ to $99 \%$ for different pressures and as the pressure was increased was decreased retaining the microorganism. Therefore, the use of mullite in bacteria-retaining membrane processes evaluated in this study showed an efficiency poor, but transmembrane flux comparable to other materials proposed in the literature.

\section{Acknowledgments}

The authors would like to acknowledge the CNPq, CAPES for financial support.

5. Das N, Maiti HS. Formatation of pore structure in tape-cast alumina membranes - effects of binder content and firing temperature. Journal of Membrane Science. 1998:140(2): 205-212. doi:10.1016/S0376-7388(97)00282-2

6. Lee M, Wang B, Wu Z, Li K. Formation of micro-channels in ceramic membranes - Spatial structure, simulation, and potential use in water treatment. Journal of Membrane Science. 2015: 483:1-14. http://dx.doi.org/10.1016/j.memsci.2015.02.023.

7. Almandoz MC, Pagliero CL, Ochoa NA, Marchese J. Composite ceramic membranes from natural aluminosilicates for microfiltration applications. Ceramics International. 2015:41(4): 5621-5633. http://dx.doi.org/10.1016/j.ceramint.2014.12.144.

8. Colle RD, Longo E, Fontes SR. Demulsification of water/ sunflower oil emulsions by a tangential filtration process using chemically impregnated ceramic tubes. Journal Membrane Science. 2007:289(1-2):58-66. http://dx.doi.org/10.1016/j. memsci.2006.11.048. 
9. Faibish RS, Cohen Y. Fouling-resistant ceramic-supported polymer membranes for ultrafiltration of oil-in-water microemulsions. Journal of Membrane Science. 2001:185(2):129-143. http:// dx.doi.org/10.1016/S0376-7388(00)00595-0.

10. Faibish RS, Cohen Y. Fouling and rejection behavior of ceramic and polymer-modified ceramic membranes for ultrafiltration of oil-in-water emulsions and microemulsions. Colloids and Surfaces A: Physicochemical and Engineering Aspects. 2001:191(12):27-40. http://dx.doi.org/10.1016/S0927-7757(01)00761-0.

11. Mulder M. Basic Principles of Membrane Technology. $2^{\text {th }}$ ed. Dordrecht, NL: Kluwer Academic; 1996.

12. Ripperger S, Altmann J. Crossflow microfiltration - State of the Art. Separation and Purification Technology. 2002;26(1):19-31. doi:10.1016/S1383-5866(01)00113-7

13. Baker RW. Membrane technology and applications. $3^{\text {th }}$ ed. California, USA: Membrane Technology and Research; 2012.

14. Montanaro L, Tulliani M, Perrot C, Negro A. Sintering of industrial mullites. Journal of the European Ceramic Society. 1997:17(14):1715-1723. http://dx.doi.org/10.1016/S09552219(97)00043-5.

15. Lv Y, Liu H, Wang Z, Liu S, Hao L, Sang Y, et al. Silver nanoparticle-decorated porous ceramic composite for water treatment. Journal of Membrane Science. 2009:331(1-2):50-56. http://dx.doi.org/10.1016/j.memsci.2009.01.007.

16. Vasanth D, Pugazhenthi G, Uppaluri R. Fabrication and properties of low cost ceramic microfiltration membranes for separation of oil and bacteria from its solution. Journal of Membrane
Science. 2011:379(1-2):154-163. http://dx.doi.org/10.1016/j. memsci.2011.05.050.

17. Bottino A, Capannelli C, Borghi AD, Colombino M, Conio O. Water treatment for drinking purpose: ceramic microfiltration application. Desalination. 2001:141(1):75-79. http://dx.doi. org/10.1016/S0011-9164(01)00390-3.

18. Wu J, Jing W, Xing W, Xu N. Preparation of W/O emulsions by membrane emulsification with a mullite ceramic membrane. Desalination. 2006:193(1-3):381-386. http://dx.doi.org/10.1016/j. desal.2005.08.026.

19. Lü Q, Dong X, Zhu Z, Dong Y. Environment-oriented low-cost porous mullite ceramic membrane supports fabricated from coal gangue and bauxite. Journal of Hazardous Materials. 2014:273:136-145. http://dx.doi.org/10.1016/j.jhazmat.2014.03.026.

20. Deng X, Wang J, Liu J, Zhang H, Li F, Duan H, Liu L, Huang Z, Zhao W, Zhang S. Preparation and characterization of porous mullite ceramics via foam-gelcasting. Ceramics International. 2015:41(7): 9009-9017. http://dx.doi.org/10.1016/j. ceramint.2015.03.237.

21. Lowell S, Shields JE. Powder surface area and porosity. $2^{\text {nd }}$ ed. New York: Chapman \& Hall; 1984.

22. Burggraaf AJ, Cot L. Fundamentals of inorganic membrane science and technology. Netherlands: Elsevier B.V.: 1996.

23. Twigg MV, Richardson JT. Structured ceramic foams as catalyst supports for highly exothermic processes. Studies in Surface Science and Catalysis. 2006:162:135-142. http://dx.doi. org/10.1016/S0167-2991(06)80900-6. 